\title{
Senyawa Goitrogenik dalam Bahan Makanan (Goitrogenik Substances in Foodstuffs)
}

\author{
YULIA LANTI RETNO DEWI \\ Bagian Biologi Fakultas Kedokteran Universitas Sebelas Maret \\ Jl. Ir. Sutami 36 A Surakarta 57126 \\ *email: yulialanti@live.com
}

Manuscript received: 17 Mei 2015 Revision accepted: 27 Juli 2015

\begin{abstract}
It has been known for a long time that iodine deficiency results in enlarged thyroid gland (goiter). However, iodine supplementation alone frequently fails to eliminate goiter in particular area. At present, experts realized that many agents interact with iodine deficiency in producing goiter. Agents that cause goiter are known as goitrogens. Several goitrogens are found in the foodstuff. Our study in Ngargoyoso sub-district revealed that several foods containing suspected such substances are consumed by school children. They are soybean cake, tofu, onion, tomato, cassava leaves, cabbage, cassava tuber and broccoli. Soybean cake and tofu are made from soybean containing isoflavone which exerts anti-thyroid activity in rats. Onion contains allyl-sulfides. Tomato, cassava leaves, and broccoli contain pigments with antioxidant moiety and anti thyroid activity. Cabbage contains isothyocyanat, a potent anti thyroid in rats and rabbits. Cassava contains linamarin. The study was a recalled study using food frequency questionnaire. In order to prove the goitrogenic activity in those foods an In-Vitro Assay or In-Vivo Assay should be carried out. Since plants grown in certain areas are influenced by soil and water, it is reasonable to measure anti thyroid activity using plants grown locally. This paper will describe those assays and suggest the most applicable in Indonesia.
\end{abstract}

Keywords: goitrogens, foodstuffs, in vitro assays, in vivo assays

\section{PENDAHULUAN}

Goiter (gondok) dipilih sebagai determinan utama untuk menentukan prevalensi dan beratnya kekurangan iodium di dalam masyarakat (WHO/VMNIS, 2014, p 1), karena praktis dan murah. Para ahli sepakat bahwa penyebab utama kejadian gondok adalah kekurangan iodium, tetapi perbedaan mencolok dijumpai pada beberapa tempat. Sebagai contoh, di pulau Idjwi, Republik Kongo di Afrika, kejadian gondok di bagian utara sepuluh kali lebih besar dari bagian tenggara, meskipun sama sama kekurangan iodium (Delange dan Ermans, 1971, p 1354). Faktor-faktor lain yang ikut berperan dalam kejadian gondok disebut goitrogen.

\section{PEMBAHASAN}

\section{Goitrogen}

Semua senyawa yang dapat menyebabkan pembesaran kelenjar gondok (tiroid) disebut goitrogen (Gaitan, 1989, p 4). Senyawa-senyawa tersebut dapat langsung mempengaruhi kelenjar tiroid atau secara tidak langsung melalui thyroid stimulating hormone (TSH). Gondok (goiter) terjadi akibat adaptasi yang salah kelenjar tiroid terhadap rangsangan TSH. Kelenjar tiroid menghasilkan hormon tiroid yang diedarkan ke dalam darah. Hormon tiroid yang beredar di dalam darah akan memberi sinyal ke kelenjar hipofise untuk mengurangi sekresi TSH. Bila hormon tiroid yang beredar sedikit, maka kelenjar hipofise akan mengeluarkan lebih banyak TSH. Bila keadaan ini berlangsung lama, maka kelenjar tiroid akan bereaksi dengan memperbesar sel-sel tirosit dan folikel tiroid, sehingga kelenjar tiroid menjadi lebih besar. Ukuran kelenjar tiroid yang membesar ini disebut goiter (gondok).

Goitrogen yang bekerja langsung terhadap kelenjar tiroid mengganggu proses sintesis hormon tiroid. Sintesis hormon tiroid ini secara garis besar dapat dibagi menjadi tiga langkah, yaitu:

1. Pengambilan iodida secara aktif dari dalam darah dan meningkatkan kadarnya di dalam kelenjar tiroid. Contoh goitrogen yang menghambat sintesis hormon tiroid pada fase ini adalah tiosianat dan isotiosianat.

2. Iodida yang telah dipekatkan di kelenjar tiroid akan mengalami oksidasi dan diikatkan pada asam amino tirosin (yang terdapat di dalam molekul tiroglobulin) menjadi monoiodotyrosine (MIT) dan diiodotyrosine (DIT). Senyawa-senyawa ini merupakan cikal-bakal hormon tiroid aktif. Proses ini disebut organifikasi dan diperantari oleh ensim tiroperoksidase. Contoh goitrogen yang menghambat sintesis hormon tiroid pada fase ini adalah golongan flavonoid, disulfidaalifatik dan goitrin.

3. Pelepasan hormon tiroid dari molekul tiroglobulin, agar dapat aktif bekerja di tempat yang dibutuhkan. Contoh goitrogen yang bekerja pada fase ini adalah iodium dosis besar dan lithium.

Goitrogen yang bekerja secara tidak langsung pada kelenjar tiroid dapat melalui hambatan pada sekresi TSH atau mengurangi efek TSH terhadap sel tirosit. Contoh goitrogen kelompok ini termasuk dinitrofenol (DNP) dan polimer flavonoid. Hormon tiroid yang telah dilepaskan oleh kelenjar tiroid akan diikat oleh molekul protein di dalam darah. Agar dapat aktif di jaringan, ikatan tersebut 
harus dibebaskan, sehingga hormon tiroid dapat masuk ke dalam sel. DNP juga menganggu proses ini. Hormon tiroid yang beredar di dalam darah terdiri dari tetraiodotyronine (T4) dan triiodotyronine (T3). T3 ini yang lebih aktif di dalam sel. Perubahan T4 menjadi T3 memerlukan ensim deiodinase. Hambatan pada enzim ini akan menurunkan aktivitas hormon tiroid. Contoh goitrogen kelompok ini adalah flavonoid (Gaitan, 1989, p 7).

\section{Goitrogen dan bahan makanan}

Kobis yang diberikan sebagai pakan pada marmot di laboratorium dapat menyebabkan pembesaran kelenjar tiroid (goiter) pertama kali ditemukan oleh Chesney et al pada tahun 1928 (Chesney et al, 1928, p 261). Setelah itu berbagai penelitian menggunakan marmot dan tikus menunjukkan bahwa berbagai macam sayuran dan bijibijian yang menjadi makanan sehari-hari dapat menyebabkan gondok(Greer, 1956, p 440)). Saat ini telah diketahui lebih dari 300 senyawa bersifat goitrogenik (Konijn et al, 1973, p 382). Yang paling banyak dijumpai dalam bahan makanan dan telah dicobakan pada binatang percobaan termasuk ke dalam golongan antithyroid sulfurated compounds (Ermans dan Bourdoux, 1989, p 15). Termasuk kelompok ini adalah tiosianat, isotiosianat, goitrin dan disulfide alifatik. Tiosianat berasal dari glukosinolate oleh ensim tioglukosidase dapat menghasilkan progoitrin. Progoitrin ini oleh kuman di dalam lumen usus seperti Escherichia coli dan Proteus vulgaris dapat diubah menjadi goitrin yang bersifat goitrogenik. Di Indonesia sayuran yang banyak mengandung tiosianat adalah kobis, kembang kobis dan brokoli. Kandungan tiosianat pada kobis 4 gr per 100 gram, sementara kembang kobis mengandung $8 \mathrm{gr} / 100$ gram bahan mentah (Ermans dan Bourdoux, 1989, p 18). Tiosianat juga dapat berasal dari glikosida sianogenik, yang banyak terdapat di dalam singkong, ubi manis dan rebung. Singkong berperan penting di dalam kejadian gondok di pulau Idjwi, Republik Kongo (Delange dan Ermans, 1971, p 1358). Glikosida sianogenik di dalam singkong adalah linamarin yang oleh ensim linamarase menghasilkan asam sianida (HCN) yang sangat beracun, maka tubuh akan mengubahnya menjadi $\mathrm{SCN}^{-}$yang kurang beracun. Linamarin juga dapat dipecah sempurna dan menghasilkan HCN oleh bakteri usus seperti golongan Klebsiella. Tiosianat telah dibuktikan menghambat ambilan (uptake) iodide oleh kelenjar tiroid. Pengaruh buruk ini dapat diatasi dengan menambahkan iodium dalam makanan. Kelompok kedua adalah isotiosianat yang banyak terdapat dalam minyak mustard yang memiliki bau khas. Alil-tiosianat terdapat dalam minyak mustard yang terdapat dalam kobis. Detoksikasi senyawa ini juga menghasilkan $\mathrm{SCN}^{-}$seperti halnya pada tiosianat. Kelompk ketiga adalah goitrin . Goitrin berasal dari progoitrin yang terdapat dalam kobis dan keluarga Brassica lainnya. Goitrin telah terbukti menyebabkan gondok endemik pada anak sekolah di Tasmania yang resiten terhadap suplementasi iodium (Erman dan Bourdoux, 1989, p 27). Kelompok berikutnya adalah disulfida alifatik yang terdapat dalam berambang dan bawang. Senyawa ini menghambat ensim tiroperoksidase.
Selain antithyroid sulfurated compounds bahan makanan juga mengandung flavonoids. Flavonoid adalah pigmen yang memberi warna tumbuh-tumbuhan, baik itu buah-buahan maupun sayuran dan biji-bijian (Cody, 1989, p 36). Flavonoids terdapat pada daun, batang, bunga dan biji tanaman dan merupakan bagian tak terpisahkan dari diet manusia baik di negara maju maupun negara berkembang. Flavonoids menurut struktur kimianya dapat dibagi menjadi 6 kelompok, yaitu: flavanones, flavones, anthocyanidins, isoflavomnes, chalcones dan aurones (Cody, 1989, 38-40). Flavanones terdapat misalnya pada anggur dan jeruk. Flavones terdapat dalam daun tanaman golongan serealia. Anthocyanidins terutama terdapat dalam sayuran berdaun, serealia, tuber (umbi) dan buah yang matang. Catechins adalah anthocyanidins yang terdapat di dalam daun teh, yang banyak diminum oleh masyarakat di Indonesia. Isoflavones banyak dijumpai pada buah polong, yang paling populer di Indonesia adalah kedelai dan hasil olahannya. Chalcones dan Aurones banyak terdapat pada bunga tanaman. Cara kerja flavonoids menghambat sintesis hormon tiroid pada fase organifikasi iodium, karena itu suplementasi iodium seringkali tidak berhasil mencegah efek goitrogeniknya. Bahan makanan tertentu dapat mengandung beberapa macam senyawa goitrogen. Senyawa ini bila dimakan oleh sapi dapat masuk ke dalam tubuh manusia terutama anak-anak melalui susu sapi (Sarne, 2010, p 10). Mengingat begitu banyaknya goitrogen di dalam makanan maka perlu dilakukan penelitian di daerah endemik kekurangan iodium, terutama yang tidak terjangkau oleh garam beriodium untuk mengetahui bahan makanan goitrogenik yang sering dikonsumsi masyarakat. Pada tahun 2013 kami meneliti pada anak sekolah dasar di kecamatan Ngargoyoso dengan menggunakan food frequency questionnaire dan mendapatkan hasil bahwa tempe, tahu, singkong, daun singkong, kobis, brokoli, bawang dan tomat merupakan bahan makanan yang sering dikonsumsi oleh anak sekolah dasar.

Goitrogen di dalam bahan makanan dapat menjelaskan tiga hal penting di masyarakat, yaitu:

1. Prevalensi gondok endemik bervariasi, meskipun suatu daerah sama-sama kekurangan iodium;

2. Gondok endemik seringkali menetap meskipun suatu daerah telah lama mendapatkan suplementasi iodium;

3. Gondok endemik dapat terjadi di daerah yang tidak kekurangan iodium.

Bahan makanan yang secara epidemiologis dapat dibuktikan menyebabkan gondok endemik adalah singkong (cassava) dan cantel (millet). Singkong perlu mendapat perhatian di Indonesia ,karena masih banyak penduduk makan singkong dan masih banyak "kantong" gondok endemik di pedesaan di Indonesia. Pada tahun 1980 produksi singkong dunia 118 juta ton, $90 \%$-nya berasal dari 25 negara, di mana 4 negara menghasilkan 53,4\%. Indonesia merupakan negara kedua setelah Brasil, dengan jumlah produksi $11,2 \%$ dari seluruh produksi singkong dunia (Delange, 1989, p 174). Bukti epidemiologis sebagai penyebab gondok endemik di jumpai pada penelitian di Nigeria, Zaire dan Malaysia. Di negara tersebut terdapat 
perbedaan mencolok di daerah-daerah yang sama-sama kekurangan iodium, tetapi berbeda konsumsi singkongnya. Singkong mengandung glikosida sianogenik (linamarin) yang oleh tubuh diolah menghasilkan isotiosianat $\left(\mathrm{SCN}^{-}\right)$ yang akan dikeluarkan melalui urine. $\mathrm{SCN}^{-}$yang tertimbun di kelenjar tiroid akan mengganggu sintesis hormon tiroid. Bila berlangsung lama dapat menimbulkan pembesaran kelenjar tiroid (gondok). Beruntunglah nenek moyang kita telah mengetahui cara-cara mengurangi kadar racun dalam singkong. Singkong yang "pahit" mengandung lebih banyak HCN dibanding dengan singkong "manis". Kandungan HCN yang dihasilkan singkong dapat dikurangi dengan pengolahan. Berikut hasil penelitian di daerah Ubangi, Zaire (Tabel 1):

Tabel 1. Kadar sianida di dalam bahan makanan segar dan siap makan di Ubangi, Zaire

\begin{tabular}{lc}
\hline \multicolumn{1}{c}{ Macam makanan } & HCN $(\mathbf{m g} / \mathbf{k g})$ \\
\hline Singkong "pahit" segar & $74,5 \pm 7,0$ \\
Singkong "manis" segar & $32,9 \pm 0,7$ \\
Daun singkong segar & $92,1 \pm 21,6$ \\
Singkongd diolah, tidak & $14,2 \pm 0,7$ \\
direndam & \\
Singkong diolah dan & $3,5 \pm 0,4$ \\
direndam & \\
Daun singkong direbus & $8,5 \pm 0,7$ \\
\hline
\end{tabular}

Sumber: Delange, 1989

Berbeda dengan singkong, cantel mengandung glikosilflavone yang menghambat aktivitas ensim tiroperoksidase. Bukti epidemiolgois dijumpai di provinsi Darfur, Sudan. Cantel juga dijumpai di Indonesia, meskipun tidak sepopuler singkong. Sebaliknya kedelai, meskipun banyak percobaan binatang menunjukkan efek goitrogeniknya, belum pernah dilaporkan bukti epidemiologisnya. Dari percobaan binatang diketahui bahwa kedelai dengan kulit berwarna (kedelai lokal) lebih goitrogenik dari kedelai tidak berwarna (kedelai impor). Masih diperlukan banyak bukti epidemiologis sebelum suatu bahan makanan dinyatakan bersifat goitrogenik bagi penduduk di suatu daerah. Oleh karena itu perlu pengujian efek goitrogenik tanaman lokal yang tumbuh di suatu daerah, apalagi bila daerah tersebut diketahui kekurangan iodium. Secara garis besar ada dua cara pengujian efek goitrogenik bahan makanan yang sudah dilakukan para ahli, yaitu pengukuran secara in vitro dan in vivo (Gaitan, 1989, p 7-10).

\section{In Vitro Assays}

Pengukuran ini dilakukan di luar tubuh hewan (penelitian pada tubuh manusia tidak dimungkinkan secara etik). Termasuk pengukuran ini adalah:

1. Penghambatan ensim tiroperoksidase (TPO). Cara ini dapat dipakai untuk mengetahui senyawa terduga yang menghambat sintesis hormon tiroid pada fase oksidasi iodide dan pembentukan MIT, DIT dan hormon tiroid di dalam kelenjar tiroid.
2. Penghambatan metabolisme iodium di dalam kelenjar tiroid. Pengukuran meliputi ambilan iodium (uptake), oksidasi iodida dan organifikasi, penggabungan (coupling) MIT dan DIT menjadi hormon tiroid aktif.

3. Penghambatan deiodinasi hormon tiroid aktif. Hormon tiroid terdiri dari 2 macam hormon yaitu T4 dan T3. Deiodinasi diperlukan untuk mengubah T4 menjadi T3 yang lebih aktif di jaringan tepi.

Pada ketiga cara pengukuran tersebut diatas bahan yang diduga dicobakan pada kelenjar tiroid binatang, diluar tubuh.

\section{In Vivo Assays}

Pengukuran di dalam tubuh hewan percobaan. Termasuk pengukuran ini adalah:

1. Penekanan aktifitas kelenjar tiroid, bisa dipakai tikus (rat) dan mencit (mice). Hambatan dapat berupa ambilan, organifikasi maupun pelepasan hormon tiroid. Pemberian senyawa terduga dilakukan segera (acute), dan dapat secepatnya diperiksa hasilnya.

2. Goitrogenisitas dan aktifitas antitiroid. Biasanya dipakai tikus (rat). Senyawa terduga diberikan sedikitsedikit untuk waktu yang lama ( \pm 30 hari), baru kemudian diperiksa hasilnya.

\section{PENUTUP}

Pemilihan pengukuran tergantung pada fasilitas laboratorium yang tersedia. Di Indonesia tidak banyak laboratorium yang memiliki iodium radioaktif yang memerlukan alat pengukur dan pengaman canggih. Pemilihan cara pengukuran juga dipengaruhi oleh biaya. Di saat dana penelitian di Indonesia masih terbatas pengukuran in vivo lebih murah, meskipun perlu waktu yang lebih lama.

\section{DAFTAR PUSTAKA}

Chesney, A.M., Clawson, T.A. ad Webster, B. (1928). Endemic goiter in rabbits; incidence and characteristics. Bulletin John Hopkins Hospital 43:261.

Cody, V. (1989). Physical and conformational properties of flavaonoids. In: Gaitan (ed): Environmental goitrogenesis, pp 36-43. CRC Press Inc. Boca Raton, Florida.

Delange, F. \& Ermans, A.M. (1971). Role of dietary goitrogen in the etiology of endemic goiter on Idjwi island. American Journal of Clinical Nutrition, 24: 1354-1360.

Delange, F. (1989). Cassava and the Thyroid, pp 179-194. In: Gaitan (ed): Environmental goitrogenesis, pp 4-11. CRC Press Inc. Boca Raton, Florida.

Erman, A.M. \& Bourdoux, P. (1989). Antithyroid Sulphurated Compounds. In: Gaitan (ed): Environmental goitrogenesis, pp 15-31. CRC Press Inc. Boca Raton, Florida.

Gaitan, E. \& Cooksey, R.C. (1989). General concept of environmental goitrogenesis. In: Gaitan (ed): Environmental goitrogenesis, pp 4-11. CRC Press Inc. Boca Raton, Florida. 
Greer, M.A. (1956). Goitrogenic Substances in Food. American Journal of Clinical Nutrition, pp 440-444. Download from ajcn.nutrition.org, January 23, 2013.

Konijn, A.M., Gershon, B., \& Guggenheim, K. (1973). Further Purification and Mode of Action of a Goitrogenic Material from Soybean Flour. Journal of Nutrition 103:378-383.

Sarne, D. (2010). Effects of Environment, Chemicals and Drugs on Thyroid Function. www. thyroidmanager.org Diakses pada tanggal 2 Juli 2015.

WHO /NMH/NHD/EPG. (2014). Goitre as a determinant of the prevalence and severity of iodine deficiency disorders in populations, pp 1-6. 